\title{
Selected Private Higher Educational Institutions In Metro Manila: A DEA Efficiency Measurement
}

Maria Corazon Gwendolyn N. de Guzman' University of Santo Tomas, Philippines Emilyn Cabanda, Regent University, USA

\begin{abstract}
This paper measures the technical efficiency of 16 selected colleges and universities in Metro Manila, Philippines, using academic data for the SY 2001 - 2005. Using the data envelopment analysis (DEA), on average, schools posted 0.807 index score and need additional 19.3\% efficiency growth to be efficient. Overall, there are top four efficient schools, with an average technical efficiency score between 99-100\%, representing 25\% of the sample. The slacks and efficient targets results have school's policy decision-making implications: Through DEA, schools have a reference set of actual values and accurate information for performance improvement on their resource allocation usage and output targets. The benchmarking characteristics of DEA may help school's administrators aspire for better performance by learning from other efficient schools.
\end{abstract}

Keywords: benchmarking, data envelopment analysis, efficiency, higher educational institutions, Philippines

\section{INTRODUCTION}

$\overbrace{}^{\text {inst }}$ $\mathrm{n}$ the Philippine educational system, private schools play a significant role. These private educational institutions have maintained a positive reputation, especially with the effective implementation of a voluntary accreditation system. Their presence basically relieves the state from providing accessible and quality education

To maintain a private educational institution, however, requires exceptional management, the ability to draw up resources, and the capacity to remain significant. Schools are beginning to accept the lessons and techniques applicable to the efficient operations of commercial and industrial organizations. With the growing complexities of many businesses, with no exception to educational institutions, there is a need for responsible management of its finances for proper utilization of its resources.

It seems education is slowly being commoditized and it is gradually evolving more of a privilege rather than a right. Even state colleges and universities have scheduled their own tuition fee hikes when they should have instead served the purpose of providing quality yet affordable education for Filipino students.

A number of studies had been made to measure the technical efficiency of different educational institutions. Avkiran (2001) made a study of Australian universities and, while no benchmark was established, based on the results from the first two models, he claimed that Australian universities are operating at "respectable" levels of efficiency. The same study of Australian universities was done by Abbott \& Doucouliagos (2003), but no inference for a higher education policy was offered in this study, though development in efficiency cannot be ruled out. In view of the fact that Australia competes for overseas students, the study stated that no conclusions can be drawn about how efficient Australian universities are compared to institutions in other systems. 
While Flegg et al. (2004) used data envelopment analysis (DEA) to measure the efficiency of British universities to reveal total factor productivity, Casu and Thanassoulis (2003) used DEA to evaluate cost efficiency in UK university central administration. The funding councils of higher education institutions have progressively evolved elaborate systems for measuring university performance in teaching quality and research. It sets up a DEA framework to identify practices leading to cost-efficient central administrative services in UK universities. Another study of UK universities was done by Joumady and Ris (2005). They found that university performance, based on the models used, showed that the DMUs were consistent as the same types of institutions were found to be efficient in those three models used.

Another paper that used DEA in the study of educational institutions was by Salerno (2002) where he made an analysis of the technical and allocative efficiency of research intensive higher educational institutions. However, the study did not address whether the mean efficiency scores can be regarded as necessarily high or low, though it was maintained that the findings are consistent with economic theories of university behavior. Thanassoulis and Portela (2002) also used the DEA-based approach to decompose pupil under-attainment into that attributable to the school or the pupil themselves. The approach measures pupil attainment in terms of value added. The results suggest that at current levels of school effectiveness, a pupil's own application accounts for the major part of his underattainment, though schools also have to improve their effectiveness.

Barnett et al. (2002) investigated the effect of size in the performance and effectiveness of secondary schools. Their findings imply that smaller size schools implies lower specialization effects, lower performance, and hence, less opportunities for the students. It was suggested that, where feasible, policy should be directed toward securing larger school size and thus better performance. Borge and Naper (2005) calculated the efficiency potential in the lower secondary school sector in Norway and analyzed the efficiency variation across local governments. The efficiency potential is calculated using DEA analysis, showing an average efficiency score of 0.78 , which yields an efficiency potential of approximately $28 \%$. Agasisti and Dal Bianco (2006) focused their study in determining the technical efficiency where Italian universities were considered, focusing on policy and benchmarking implications. Using DEA, their study chose to focus on the single elaboration, selected on statistical grounds, to derive some policy implications.

Most recent studies conducted on the performance of private higher educational institutions in the Philippines were either very limited in terms of data sample or much broader in scope. The study of Fernando and Cabanda (2007) concentrated on measuring the efficiency of only one school by comparing the different income generating colleges and departments of the University of Santo Tomas. Another study by Castano and Cabanda (2007) examined the sources of efficiency performance for the Philippine state universities and colleges. Their study has a broader scope, covering a big sample of Philippine public higher educational institutions only. However, the research has not yet been done on efficiency evaluation of private universities, with a concentration only on the greater metropolitan area or the capital of the Philippines, which is Metro Manila, using an extended model of data envelopment analysis. The reason for limiting the scope of this study to Metro Manila is only primarily logistical, but the focus has also conceptual strengths. Baseline data in this study allow analysis of trends in different localities in the Philippines, the type of educational institutions, and other topics. Producing a volume that covered all of these topics would be formidable and lengthy, unlike concentrating only on one location so as to develop a more comprehensive picture and measurement of the efficiency of different educational institutions on the said location.

There is a need for a paper to be conducted to evaluate the efficiency of different colleges and universities, including the financial aspect, as well as to draw up measures on how to improve the performance of different educational institutions. This paper aims to measure the average technical efficiency of different selected schools and to derive a reference set for inefficient schools for benchmarking efficient schools.

In the next section, discussions on the basic concepts of DEA and data sample are introduced. Results are discussed in Section 3 and finally, concluding remarks are found in Section 4. 


\section{METHODOLOGY AND DATA SAMPLE}

\subsection{Overview of Data Envelopment Analysis}

DEA is a relatively new "data oriented" approach for evaluating the performance of a set of peer entities called decision-making units (DMUs), which convert multiple inputs into multiple outputs. The definition of a DMU is generic and flexible. Recent years have seen a great variety of applications of DEA for use in evaluating performances of many different kinds of entities engaged in several activities in various different contexts in different countries. These DEA applications have used DMUs of various forms to evaluate the performance of entities, such as hospitals, US Air Force wings, universities, cities, courts, business firms, and others, including the performance of countries, regions, etc. Because it requires very few assumptions, DEA has also opened up possibilities for use in cases which have been resistant to other approaches because of the complex (often unknown) nature of the relations between the multiple inputs and multiple outputs involved in DMUs (Cooper, Seiford and Zhu, 2004).

DEA has also been used to supply new insights into activities (and entities) that have previously been evaluated by other methods. For instance, studies of benchmarking practices with DEA have identified numerous sources of inefficiency in some of the most profitable firms: firms that had served as benchmarks by reference to this (profitability) criterion - and this has provided a vehicle for identifying better benchmarks in many applied studies (Cooper, Seiford and Zhu, 2004, p. 2).

In the seminal paper of Charnes, Cooper, and Rhodes (1978), they applied DEA (and so with this present paper) in a non-profit sector, wherein, the measurement of performance is more complex than in the profit sector in which the single indicator is profitability. Further, they described DEA as a mathematical programming model applied to observational data that provides a new way of obtaining empirical estimates of relations - such as the production functions and/or efficient production possibility surfaces - that are cornerstones of modern economics. Formally, DEA is a methodology directed to frontiers rather than central tendencies. Instead of trying to fit a regression plane through the center of the data as in statistical regression, one "floats" a piecewise linear surface to rest on top of data observations. For example, consider what one wants to mean by "efficiency", or more generally, what one wants to mean that one DMU is more efficient than another DMU. This is accomplished in a direct manner by DEA without requiring explicitly formulated assumptions and variations with various types of models such as in linear and nonlinear regression models (Cooper, Seiford and Zhu, 2004, p. 3) .

The paper uses the slack-based DEA model, specifically the variable returns to scale (VRS), that allows the calculation of technical efficiency measures that can be either input or output oriented.

\subsection{Input Orientated Variable Returns to Scale DEA Model}

The DEA model adopted in this paper is an input-oriented VRS model as follows (Gang \& Felmingham, 2002 ):

$$
\begin{array}{lr} 
& \min _{\theta, \lambda, S+, S-} \mathrm{TE}=\theta-\varepsilon\left(\mathbf{1 s}^{+}+\mathbf{1} \mathrm{s}^{-}\right) \\
\text {s.t. } & \\
& \mathrm{Y} \lambda-\mathrm{s}^{+}=\mathrm{Yo} \\
& \\
& \mathbf{X} 0-\mathrm{X} \lambda-\mathrm{s}^{-}=0 \\
\mathbf{1} \lambda=1 \\
\lambda, \mathrm{s}^{+}, \mathrm{s}^{-} \geq 0
\end{array}
$$

where TE is the technical efficiency score and the variable $\theta$ is the (proportional) reduction applied to all inputs of $\mathrm{DMU}_{0}$ ( the DMU being evaluated ) to improve efficiency, $\lambda$ is the value of constructing a composite unit with inputs $\mathrm{Y} \lambda$ and outputs $\mathrm{X} \lambda$ outperforming $\mathrm{DMU}_{0}, \varepsilon$ allows the minimization over $\theta$ to preempt the optimization involving the slack variables s ${ }^{+}$and $\mathrm{s}^{-}$, the variables $\mathrm{s}+$ and $\mathrm{s}$ - represent the excess inputs and output slacks and are the distance between an inefficient $\mathrm{DMU}(\mathrm{X} 0, \mathrm{Y} 0)$ and its projected point $\left(\mathrm{X}_{0}=\theta \mathrm{X} 0-\mathrm{s}^{-}, \hat{\mathrm{Y}}_{0}=\mathrm{Y}_{0}+\mathrm{s}^{+}\right)$on the 
envelopment surface of efficiency frontier. As can be seen, an input oriented VRS model, focuses on the maximal movement towards the frontier through a proportional reduction of inputs, given the output level (Gang \& Felmingham, 2002, p. 8).

Input orientated is used in this paper to indicate that an inefficient unit may be made efficient by reducing the proportions of its inputs but keeping the output proportions constant. VRS model is adopted in this paper with the assumption that not all schools are operating at optimal scale due to financial constraints and varied student populations.

\subsection{Slacks}

The linear programming input-orientated DEA model with slacks may defined by:

$$
\begin{gathered}
\min _{\lambda, \mathrm{OS}, \mathrm{IS}}-\left(\mathrm{M} 1^{\prime} \mathrm{OS}+\mathrm{K} 1^{\prime} \mathrm{IS}\right), \\
\text { st } \quad-\mathrm{y}_{\mathrm{i}}+\mathrm{Y} \lambda-\mathrm{OS}=0, \\
\theta \mathrm{x}_{\mathrm{i}}-\mathrm{X} \lambda-\mathrm{IS}=0, \\
\lambda \geq 0, \mathrm{OS} \geq 0, \mathrm{IS} \geq 0,
\end{gathered}
$$

where OS is an M x 1 vector of output slacks, IS is a $\mathrm{K} x 1$ vector of input slacks, and $\mathrm{M} 1$ and $\mathrm{K} 1$ are $\mathrm{M} \mathrm{x} 1$ and $\mathrm{K} \times$ 1 vectors of ones, respectively. Note that in this linear program, $\theta$ is not a variable, its value is taken from the first results. Furthermore, note that this linear program must also be solved for each of the N DMU's involved (Ramanathan, 2003).

\subsection{Data Samples and Variables}

Table 1 lists 16 decision-making units (DMUs) that represent the selected private higher educational institutions. The study employs two input measures: capital expenditures and total operating expenses. Capital expenditures refer to those assets acquired on a long-term basis and that are not purchased or sold in the normal course of business. Generally, these include fixed assets, e.g., land, buildings, furniture, equipment, fixtures and furniture. Total operating expenses incurred are costs incurred in the normal course of business to generate revenues. Financial data such as capital and operating expenditures are common input variables used in the study of educational institutions such as studies done by Abbott and Doucouliagos (2003) and Taylor and Harris (2005).

The study also employs three output measures: total number of students, total number of graduate students, and total revenues. Total number of students refers to the total number of enrollees during the school year. Total number of graduates refers to the number of students who graduated at the end of the school year. Total educational income consists of all direct educational income from school operations, net of allowances and discounts granted but exclude other incomes derived by the schools such as interest income and rental income as the case maybe. In the study made by Agasisti and Dal Bianco (2006), the number of students and graduates were used as output variables. The total educational income was used as an output variable by Casu and Thanassoulis (2003) when they evaluated the cost efficiency of the central administrative departments in UK universities.

This paper is limited to the analysis of the 16 selected private higher educational institutions in Metro Manila, covering the period from SY 2001-2005. The data used were extracted from the financial statements duly audited and submitted to the Securities and Exchange Commission and from the statistics reports gathered from different schools and CHED.

\section{FINDINGS}

By the evaluation outcomes, as shown in Table 1, there are two technically efficient schools; namely, UST and FEU, and four relatively efficient; namely, Sta. Catalina, St. Jude, Mapua and CEU, representing $37.5 \%$ of the sample. Out of the 16 samples, only one got a technical efficiency score of 80-89\% and that is JRU. Most of the samples got an overall score of 60-79\%, representing 56.3\%. The 16 DMU's got an average technical efficiency score of $80.7 \%$, requiring an additional $19.31 \%$ efficiency growth. 
Table 1

Overall Technical Efficiency Ranking

Input - Oriented - VRS Model

\begin{tabular}{|c|c|c|c|c|c|c|c|c|}
\hline Schools & 2001 & 2002 & 2003 & 2004 & 2005 & Average & $\begin{array}{c}\text { DEA } \\
\text { RANKING }\end{array}$ & $\begin{array}{c}\text { \% DEFICIT } \\
\text { TO THE } \\
\text { EFFICIENCY } \\
\text { FRONTIER }\end{array}$ \\
\hline
\end{tabular}

\begin{tabular}{|c|c|c|c|c|c|c|c|c|}
\hline ACQC & 0.694 & 0.728 & 0.674 & 0.566 & 0.586 & 0.649 & 11 & 35.055 \\
\hline CSJL & 0.826 & 0.677 & 0.615 & 0.634 & 0.629 & 0.676 & 10 & 32.372 \\
\hline UST & 1.000 & 1.000 & 1.000 & 1.000 & 1.000 & 1.000 & 1 & 0.000 \\
\hline SCC & 1.000 & 0.986 & 1.000 & 1.000 & 1.000 & 0.997 & 2 & 0.287 \\
\hline SICO & 0.802 & 0.799 & 0.728 & 0.737 & 0.651 & 0.743 & 8 & 25.677 \\
\hline SJC & 1.000 & 1.000 & 1.000 & 1.000 & 0.987 & 0.997 & 2 & 0.257 \\
\hline SBC & 0.588 & 0.633 & 0.627 & 0.651 & 0.636 & 0.627 & 13 & 37.275 \\
\hline CEU & 1.000 & 0.867 & 0.911 & 0.929 & 0.821 & 0.906 & 4 & 9.432 \\
\hline UE & 1.000 & 0.641 & 0.607 & 0.595 & 0.597 & 0.688 & 9 & 31.185 \\
\hline TUOA & 0.724 & 0.746 & 0.750 & 0.801 & 0.749 & 0.754 & 7 & 24.607 \\
\hline FEU & 1.000 & 1.000 & 1.000 & 1.000 & 1.000 & 1.000 & 1 & 0.000 \\
\hline JRU & 1.000 & 0.958 & 0.825 & 0.930 & 0.736 & 0.890 & 5 & 11.014 \\
\hline MAPUA & 0.948 & 1.000 & 0.979 & 1.000 & 0.834 & 0.952 & 3 & 4.783 \\
\hline DOMC & 0.772 & 0.727 & 0.894 & 0.800 & 0.646 & 0.768 & 6 & 23.218 \\
\hline DBC & 0.598 & 0.618 & 0.627 & 0.625 & 0.649 & 0.623 & 14 & 37.654 \\
\hline ADMU & 0.575 & 0.575 & 0.576 & 0.576 & 0.888 & 0.638 & 12 & 36.203 \\
\hline All Schools & 0.845 & 0.810 & 0.801 & 0.803 & 0.776 & 0.807 & & 19.314 \\
\hline
\end{tabular}

Table 2

Number of Schools with Input Oriented IRS Efficiency

\begin{tabular}{|c|c|c|c|c|c|c|c|}
\hline & Schools & 2001 & 2002 & 2003 & 2004 & 2005 & TOTAL \\
\hline 1 & ANGELICUM & $\mathrm{X}$ & $\mathrm{X}$ & $\mathrm{X}$ & $\mathrm{X}$ & $\mathrm{X}$ & 5 \\
\hline 2 & LETRAN & $\mathrm{X}$ & $\mathrm{X}$ & $X$ & $X$ & $X$ & 5 \\
\hline 3 & UST & & & & & & \\
\hline 4 & STA. CATALINA & $\mathrm{X}$ & $\mathrm{X}$ & $X$ & $\mathrm{X}$ & $\mathrm{X}$ & 5 \\
\hline 5 & SIENA COLLEGE & $X$ & $\mathrm{X}$ & $X$ & $X$ & $X$ & 5 \\
\hline 6 & ST. JUDE COLLEGE & & & & & & \\
\hline 7 & SAN BEDA COLLEGE & $\mathrm{X}$ & $\mathrm{X}$ & $\mathrm{X}$ & $\mathrm{X}$ & $\mathrm{X}$ & 5 \\
\hline 8 & CEU & & & & & & \\
\hline 9 & UE & & & & $\mathrm{X}$ & & 1 \\
\hline 10 & TRINITY & $\mathrm{X}$ & & $\mathrm{X}$ & & $\mathrm{X}$ & 3 \\
\hline 11 & FEU & & & & & & \\
\hline 12 & JRU & & & $\mathrm{X}$ & & $\mathrm{X}$ & 2 \\
\hline 13 & MAPUA & $X$ & & & & $\mathrm{X}$ & 2 \\
\hline 14 & DE OCAMPO & $\mathrm{X}$ & $\mathrm{X}$ & $\mathrm{X}$ & $\mathrm{X}$ & $\mathrm{X}$ & 5 \\
\hline 15 & DON BOSCO & $\mathrm{X}$ & $X$ & $X$ & $X$ & $\mathrm{X}$ & 5 \\
\hline \multirow[t]{2}{*}{16} & ATENEO & $\mathrm{X}$ & $\mathrm{X}$ & $\mathrm{X}$ & $X$ & & 4 \\
\hline & TOTAL & 10 & 8 & 10 & 9 & 10 & 47 \\
\hline
\end{tabular}

Note: The school marked with X represents the efficiency IRS in a given year

Tables 2, 3 and 4 show the performance of the different DMU's during the five-year period for the constant, increasing and decreasing returns to scale (DRS). The X represents the number of counts that the schools has reached the said scale efficiency level. Table 3 shows the schools operating at increasing returns to scale (IRS), where the output increases for these schools were more than in proportion to inputs. It is worthy to note that seven out of 16 schools were consistently on such scale efficiency during the five-year test period; namely, Angelicum, 
Letran, Sta. Catalina, Siena, San Beda, De Ocampo and Don Bosco. Table 4 lists the schools operating at constant returns to scale (CRS) where the output increases are just in proportion to input increases. Results show that only St. Jude has been consistently operating on such scale over the four-year period. In Table 5, the schools operating at a decreasing returns to scale are listed where the output increases are less than in proportion to the inputs. As can be noted, UST and CEU were the only schools that were consistently operating at decreasing returns to scale. Based on aforementioned tables, the results show that during the five-year period, most of the schools were operating under the increasing returns to scale. On average, there were 47 counts of IRS performance (58.8\%), 24 counts of DRS (30\%) and 9 counts of CRS (11.3\%).

As discussed by Nyhan and Cruise (2000), DEA's advantage over previous statistical applications includes the ability to measure multiple input and output variables and to provide a single measure of performance, as well as a scalar ranking of organizations within the sample. Furthermore, efficient organizations can be used as benchmarks to identify slack in the production process. In addition, DEA can provide longitudinal analysis through optimization. Inefficiently used inputs or inefficiently produced outputs generate slacks. These slacks reflect either surpluses (inputs) or shortages (outputs) in production. Slacks can be analyzed to determine which inputs or outputs contribute the most to inefficient DMUs computed efficiency scores.

Table 3

Number of Schools with Input Oriented CRS Efficiency

\begin{tabular}{|c|c|c|c|c|c|c|c|}
\hline & Schools & 2001 & 2002 & 2003 & 2004 & 2005 & TOTAL \\
\hline 1 & ANGELICUM & & & & & & \\
\hline 2 & LETRAN & & & & & & \\
\hline 3 & UST & & & & & & \\
\hline 4 & STA. CATALINA & & & & & & \\
\hline 5 & SIENA COLLEGE & & & & & & \\
\hline 6 & ST. JUDE COLLEGE & $X$ & $\mathrm{X}$ & $X$ & $X$ & & 4 \\
\hline 7 & SAN BEDA COLLEGE & & & & & & \\
\hline 8 & CEU & & & & & & \\
\hline 9 & UE & & & & & & \\
\hline 10 & TRINITY & & & & & & \\
\hline 11 & FEU & $\mathrm{X}$ & $\mathrm{X}$ & & & & 2 \\
\hline 12 & JRU & $X$ & & & & & 1 \\
\hline 13 & MAPUA & & $\mathrm{X}$ & & $\mathrm{X}$ & & 2 \\
\hline 14 & DE OCAMPO & & & & & & \\
\hline 15 & DON BOSCO & & & & & & \\
\hline \multirow[t]{2}{*}{16} & ATENEO & & & & & & \\
\hline & TOTAL & 3 & 3 & 1 & 2 & $\mathbf{0}$ & 9 \\
\hline
\end{tabular}

Note: The school marked with X represents the efficiency CRS in a given year.

Table 5 shows the percentage summary of input slacks per DMU during the period 2001-2005. Slacks are identified only for inefficient DMUs. Under the capital assets, three (3) out of 16 schools have been classified as inefficient due to the presence of slacks. CEU has the highest capital asset slacks (15.475\%), followed by Mapua $(15.170 \%)$ and Sta. Catalina $(3.177 \%)$. Findings show that these three (3) schools exceeded their spending on capital assets. For the total expenses, there are twelve (12) schools that were efficient since all those posted zero slacks. On average, all schools incurred slacks of $2.114 \%$ in terms of capital assets and $1.620 \%$ in total expenses.

Based on Table 6, only UST and FEU were efficient in getting the number of students. The same situation is found in the number of graduates with almost the same schools having the highest percentage slacks. The only difference is in their ranking. As for the educational income, only 12 out of 16 schools have the presence of slacks. San Beda College got the highest percentage of about $25.016 \%$ income deficits. UST, CEU, FEU and Mapua all had been efficient in meeting their targets for their income since all posted zero slacks. In summary, all 16 schools have average percentage slacks in number of students for about $291.616 \%$, number of graduates of $259.931 \%$ and educational income of $8.518 \%$. 
Table 4

Number of Schools with Input Oriented DRS Efficiency

\begin{tabular}{|c|c|c|c|c|c|c|c|}
\hline & Schools & 2001 & 2002 & 2003 & 2004 & 2005 & TOTAL \\
\hline 1 & ANGELICUM & & & & & & \\
\hline 2 & LETRAN & & & & & & \\
\hline 3 & UST & $\mathrm{X}$ & X & $\mathrm{X}$ & X & $\mathrm{X}$ & 5 \\
\hline 4 & STA. CATALINA & & & & & & \\
\hline 5 & SIENA COLLEGE & & & & & & \\
\hline 6 & ST. JUDE COLLEGE & & & & & $\mathrm{X}$ & 1 \\
\hline 7 & SAN BEDA COLLEGE & & & & & & \\
\hline 8 & CEU & $\mathrm{X}$ & $\mathrm{X}$ & X & X & $\mathrm{X}$ & 5 \\
\hline 9 & UE & $\mathrm{X}$ & $\mathrm{X}$ & $\mathrm{X}$ & & $\mathrm{X}$ & 4 \\
\hline 10 & TRINITY & & $\mathrm{X}$ & & $X$ & & 2 \\
\hline 11 & FEU & & & $\mathrm{X}$ & $\mathrm{X}$ & $\mathrm{X}$ & 3 \\
\hline 12 & JRU & & $\mathrm{X}$ & & $\mathrm{X}$ & & 2 \\
\hline 13 & MAPUA & & & $\mathrm{X}$ & & & 1 \\
\hline 14 & DE OCAMPO & & & & & & \\
\hline 15 & DON BOSCO & & & & & & \\
\hline 16 & ATENEO & & & & & $\mathrm{X}$ & 1 \\
\hline & TOTAL & 3 & 5 & 5 & 5 & 6 & 24 \\
\hline
\end{tabular}

Note: The school marked with X represents the efficiency DRS in a given year.

Table 5

Summary of Average Input Slacks, 2001-2005 (\%)

\begin{tabular}{llcc}
\hline & Schools & $\begin{array}{c}\text { Capital } \\
\text { Assets }\end{array}$ & $\begin{array}{c}\text { Total } \\
\text { Expenses }\end{array}$ \\
\hline & ANGELICUM & 0 & 0 \\
2 & LETRAN & 0 & 0 \\
3 & UST & 0 & 0 \\
4 & STA. CATALINA & 3 & 0 \\
5 & SIENA COLLEGE & 0 & 0 \\
6 & ST. JUDE COLLEGE & 0 & 0 \\
7 & SAN BEDA COLLEGE & 0 & 0 \\
8 & CEU & 15 & 2 \\
9 & UE & 0 & 3 \\
10 & TRINITY & 0 & 0 \\
11 & FEU & 0 & 0 \\
12 & JRU & 0 & 0 \\
13 & MAPUA & 15 & 1 \\
14 & DE OCAMPO & 0 & 0 \\
15 & DON BOSCO & 0 & 20 \\
16 & ATENEO & 0 & $\mathbf{2}$ \\
\hline
\end{tabular}

Slacks can further be explained by the efficient target levels derived from the DEA models. Reichmann (2004) argued that one of the advantages of DEA is that it provides quantitative information on the extent of inefficiency and, subsequently, on the targets required to become efficient. Later the targets can be discussed in a dynamic, strategic set up, that gives all organizations, including the "best practices", a possible new look at their strategies. Differences between the "best-practice" organization and the others are used as information nodes (Langberg, 2002).

Table 7 show the efficient target for capital assets. In capital assets, only three schools were not able to meet their targets; namely, CEU, Mapua, and Sta. Catalina, while in total expenses, Ateneo, UE, Mapua and CEU have not reached their target. This result proves the presence of slacks for the aforementioned schools since there was surplus found in the utilization of their capital assets and exceeded their spending in the expenses for their operations. 
Table 6

Summary of Average Output Slacks, 2001-2005 (\%)

\begin{tabular}{lllll}
\hline & Schools & $\begin{array}{l}\text { Number Of } \\
\text { Students }\end{array}$ & $\begin{array}{l}\text { Number Of } \\
\text { Graduates }\end{array}$ & $\begin{array}{l}\text { Educ } \\
\text { Income }\end{array}$ \\
\hline 1 & ANGELICUM & 1775 & 1640 & 14 \\
2 & LETRAN & 240 & 549 & 17 \\
3 & UST & 0 & 0 & 0 \\
4 & STA. CATALINA & 50 & 3 & 1 \\
5 & SIENA COLLEGE & 741 & 229 & 7 \\
6 & ST. JUDE COLLEGE & 0 & 0 & 1 \\
7 & SAN BEDA COLLEGE & 305 & 283 & 25 \\
8 & CEU & 39 & 0 & 0 \\
9 & UE & 109 & 57 & 22 \\
10 & TRINITY & 232 & 124 & 3 \\
11 & FEU & 0 & 0 & 0 \\
12 & JRU & 19 & 34 & 0 \\
13 & MAPUA & 17 & 25 & 14 \\
14 & DE OCAMPO & 223 & 87 & 16 \\
15 & DON BOSCO & 710 & 986 & 3 \\
\hline
\end{tabular}

Table 7

Efficient Targets in Capital Assets

For Inefficient Schools (actual values in millions )

\begin{tabular}{|c|c|c|c|c|c|c|}
\hline Schools & 2001 & 2002 & 2003 & 2004 & 2005 & Average \\
\hline $\begin{array}{l}\text { ANGELICUM } \\
\text { LETRAN } \\
\text { UST } \\
\text { STA. CATALINA } \\
\text { SIENA COLLEGE } \\
\text { ST. JUDE COLLEGE } \\
\text { SAN BEDA COLLEGE } \\
\text { CEU } \\
\text { UE } \\
\text { TRINITY } \\
\text { FEU } \\
\text { JRU } \\
\text { MAPUA } \\
\text { DE OCAMPO } \\
\text { DON BOSCO } \\
\text { ATENEO }\end{array}$ & 51 & 63 & 35 & 46 & & $\begin{array}{c}0 \\
0 \\
0 \\
0 \\
0 \\
0 \\
0 \\
31 \\
0 \\
0 \\
0 \\
0 \\
17 \\
0 \\
0 \\
0\end{array}$ \\
\hline
\end{tabular}

Note: All the shaded portions in this table represent schools that have reached their targets for the given year..

With Table 8 as a sample, UST and FEU consistently reached their efficient targets for the number of students, graduates and educational income. The extent to which a school is efficient in producing graduates is linked to its quality of student intake and its effect is extended to its income for the said year.

The fundamental idea behind benchmarking process is that one or more organizations are identified as "best practice" in a specific area, and that the organizations together enter into a learning process, where the "best practice" is the representation of the target in the first round (Langberg, 2002). Nowadays, the concept of benchmarking is not uncommon, especially in higher education. Simply put, benchmarking is about learning from the "industry leaders", but measures each institution by comparing it to the best performance only in the designated peer group. 
Table 8

Efficient Targets in Educational Income

For Inefficient Schools (actual values in millions)

\begin{tabular}{|c|c|c|c|c|c|c|}
\hline Schools & 2001 & 2002 & 2003 & 2004 & 2005 & Average \\
\hline ANGELICUM & 69 & & 80 & 78 & 81 & 62 \\
\hline LETRAN & & 223 & 226 & 241 & 234 & 185 \\
\hline UST & & & & & & 0 \\
\hline STA. CATALINA & & 14 & & & & 3 \\
\hline SIENA COLLEGE & & & 67 & 72 & 85 & 45 \\
\hline ST. JUDE COLLEGE & & & & & 75 & 15 \\
\hline SAN BEDA COLLEGE & 258 & 264 & 267 & 283 & 332 & 281 \\
\hline CEU & & & & & & 0 \\
\hline UE & & 683 & 825 & 842 & 741 & 618 \\
\hline TRINITY & 166 & 196 & 228 & 253 & 307 & 230 \\
\hline FEU & & & & & & 0 \\
\hline JRU & & 176 & 197 & 231 & 279 & 177 \\
\hline MAPUA & & & & & & 0 \\
\hline DE OCAMPO & 49 & 43 & & 61 & 73 & 45 \\
\hline DON BOSCO & 101 & 106 & 114 & 193 & 188 & 140 \\
\hline ATENEO & 937 & 1062 & & & & 400 \\
\hline All Schools & 99 & 173 & 125 & 141 & 150 & 138 \\
\hline
\end{tabular}

Note: All the shaded portions in this table represent schools that have reached their targets for the given year.

Out of the sixteen (16) schools, FEU is the most efficient when considering the number of times it was used by the other schools as a benchmark Although on the overall average technical efficiency ranking, it ranked the same with UST, which the latter got only 19 counts. As to scale efficiency, it had met and maintained consistently its target in all the input and output variables considered over the test period. FEU's efficiency was resulted from its increase in its educational income, especially in the school year $2002-2003$. It has very minimal outflow when it comes to capital assets. However, when it comes to operating expenses, it continuously increased over the five- year period.

As a summary, the paper revealed that the private higher educational institutions in Metro Manila are $81 \%$ efficient based on an input-orientated variable returns to scale and is $19 \%$ deficit to the efficiency frontier. The new finding implies that these private higher educational institutions are relatively efficient during the test period.

\section{CONCLUSIONS}

DEA made it possible to measure the degree of variation in efficiency across the sector as a whole and identified possible sources of inefficiency. An important feature of DEA employed in this paper is its ability to allocate a score and the necessary input reduction needed to achieve the technical efficiency that can be obtained. Hence, the identification of inefficient resources would lead to improved competitiveness within the education sector.

In summary, aside from FEU, UST also obtained an overall technical efficiency score of $100 \%$ and did not incur any input/output slacks, so it continuously maintained its target during the test period. However, UST was used only as a benchmark of the other inefficient schools for 19 counts, compared with other schools.

It is evident why DEA was used and is being used in the examination and measurement of technical efficiency of educational institutions. Further, this approach seeks to explain the slack inefficiency in each unit as evident in this present paper; that is, slack in the form of excessive utilization of specific resources or underprovision of outputs. This analysis is likely to illuminate areas of particular concern to school's management.

The empirical findings of this paper, then, have the following implications: The management of the different schools should make an evaluation of their performance in relation to other schools of its class. These 
results suggest that strategies in improving efficiency, such as setting a limitation to their investment in capital assets and spending in operating expenses, should be strictly imposed. Inefficient schools may learn from the efficient ones to improve their overall performance and efficiency.

Finally, the results of this paper have school's policy decision-making implications. Through DEA, schools have a reference set of actual values and accurate information for performance improvement on their resource allocation usage and output targets. The benchmarking characteristics of DEA may help the different school's administrators to aspire for better performance by learning from the efficient schools.

For future research of educational institutions, this study offers possible recommendations (the present limitations of this study): to expand the data set to include more input and output variables to form a more useful basis for inter-school benchmarking and to seek other strategies for performance improvement in relation to efficiency, as well as an extension to a longer time period of analysis. Moreover, additional panel of data could also be utilized for other quantitative approaches for efficiency evaluation. Likewise, other non-discretionary factors, such as age, structure, and size, should also be considered in the selection of DMUs, as well as how these factors may impact the efficiency of the said DMUs.

Lastly, this paper serves as a guide to managerial action or policy-making decisions in the education sector. DEA solutions can be used to gain a better understanding on why other DMUs are located on the efficient frontier while others are not; and therefore, they are inefficient. For managerial and organizational effectiveness, attention will need to focus on identifying the various organizational factors, such as policies, processes, etc. that account for the differences in performance. In the final analysis, the objective will be to determine the changes to be adopted that will contribute to educational efficiency.

\section{ACKNOWLEDGENT}

Our acknowledgement to the UST Graduate School, UST Accounting Department and the UST Research and Endowment Foundation for the subsidies granted when this paper was presented in the 2008 International Business \& Economic Research conference held in Las Vegas, Nevada on September 28-October 2, 2008. Comments on the session participants are greatly acknowledged. The usual disclaimer prevails.

\section{AUTHOR INFORMATION}

Maria Corazon Gwendolyn N. De Guzman is a certified public accountant and has been working at the University of Santo Tomas Accounting Department in the Philippines as a General Accounting Supervisor. She also has completed her Masters in Business Administration at the same university

Dr Emilyn Cabanda is an Associate Professor at the School of Global Leadership and Entrepreneurship, Regent University, 1333Regent University Drive, Suite 102, Virginia Beach, VA 23464, USA and serves as an adjunct professor at the University of Santo Tomas in the Philippines. She has published numerous articles in peer-reviewed journals in operations research and management science in education, manufacturing, and service sectors. She coauthored a book on Performance Management: Applications of Data Envelopment Analysis in the Philippine Setting by the University of Santo Tomas Publishing House.

\section{REFERENCES}

1. Abbott, M and Doucouliagos, C. (2003). The Efficiency of Australian Universities A Data Envelopment Analysis. Economics of Education Review, Vol 22, pp. 89-97.

2. Agasisti, T. and Dal Bianco, A. (2006) . Reforming the University Sector: Effects on Teaching Efficiency Evidence from Italy. Department of Management, Economics and Industrial Engineering, Politencio de Milano, Technical University, Italy , pp. 344-367.

3. Avkiran, N. (2001) . Investigating Technical and Scale Efficiencies of Australian Universities Through Data Envelopment Analysis. Socio - Economic Planning Sciences, Vol. 35, pp 57-80. 
4. Barnett, R., Glass, J., Snowdon, R., and Stringer, K. (2002). Size, Performance and Effectiveness: CostConstrained Measures of Best Practice Performance and Secondary -School Size. Education Economics, Vol. 10(3), pp 291 - 311.

5. Borge, L. and Naper, L. (2005). Efficiency Potential and Efficiency Variation in Norwegian Lower Secondary Schools. CESIFO Working Paper, No. 1624, pp 1-27.

6. Castano, M. and Cabanda, E. (2007). Sources of Efficiency and Productivity Growth in the Philippine State Universities and Colleges: A Non-Parametric Approach. International Business and Economics Research Journal, Vol. 6(6), pp. 79-90.

7. Casu B. and Thanassoulis E. (2003). Evaluating Cost Efficiency in Central Administrative Services in UK Universities . Aston Business School Research Papers, Aston Business School Birmingham, UK, pp. 136.

8. Cooper W., Seiford, L. and Zhu, J. (2004). Data Envelopment Analysis: Models and Interpretation. Kluwer Academic Publisher, Boston, pp. 1-39.

9. Fernando, B. and Cabanda, E. (2007). Measuring Efficiency and Productive Performance of Colleges at the University of Santo Tomas A Non - Parametric Approach. International Transactions in Operational Research, Vol 14 (3), pp 217-229.

10. Flegg, A., Allen, D., Field, K. and Thurlow, T. (2004). Measuring the Efficiency of British Universities: A Multi-Period Data Envelopment Analysis. Education Economics, Vol. 12(3), pp. 232-249

11. Gang, L and Felmingham, B. (2002). The Technical Efficiency of Australian Irrigation Schemes. Managed Care Quarterly, Vol 8 (1), pp 18-27.

12. Joumady, O. and Ris, C. (2005). Performance in European Higher Education: A Non - Parametric Production Frontier Approach. Education Economics, Vol. 13(2), pp. 189-205.

13. Langberg, K. (2002). Benchmarking and Ranking of Publications. The Danish Institute for Studies in Research Policy, Finland, pp. 1-51.

14. Nyhan, R. and Cruise, P. (2000). Comparative Performance Assessment in Managed Care: Data Envelopment Analysis for Health Care Managers. Managed Care Quarterly, Vol 8 (1), pp 18-27.

15. Ramanathan R., (2003). An Introduction to Data Envelopment Analysis: A Tool for Performance Measurement. Sage Publications, New Delhi, pp. 33-35.

16. Reichmann, G. (2004). Measuring University Library Efficiency Using Data Envelopment Analysis. Libri: International Journal of Libraries \& Information Services 2004, Vol. 54 ,pp 136-146.

17. Salerno, C. (2002). On the Technical and Allocative Efficiency of Research-Intensive Higher Education Institutions. The Pennsylvania State University: University Park, PA, pp. 1-11.

18. Taylor, B. and Harris, G. (2004). Relative Efficiency among South African Universities: A Data Envelopment Analysis. Higher Education, Vol. 47 pp. 73-89.

19. Thanassoulis, E. and Portela, A. (2002). School Outcomes: Sharing the Responsibility Between Pupil and School. Education Economics, Vol. 10(2), pp 183-207. 
NOTES 